\title{
O TESTEMUNHO DO CARRASCO: DA MEMÓRIA AO RESSENTIMENTO EM As BENEVOLENTES
} Lara Luiza Oliveira Amaral ${ }^{*}$

(D) https://orcid.org/0000-0002-6870-3576

Como citar este artigo: AMARAL, L. L. O. O testemunho do carrasco: da memória ao ressentimento em As Benevolentes. Todas as Letras - Revista de Lingua e Literatura, São Paulo, v. 22, n. 3, p. 1-16, set./dez. 2020. DOI 10.5935/1980-6914/eLETLL 2012310

Submissão: março de 2019. Aceite: abril de 2020.

Resumo: Um escritor nova-iorquino que escreve seu romance em francês. Uma descendência judaica que se contorce e se transforma em uma narrativa contada pelos olhos de um oficial nazi. Invertemos os papéis em As Benevolentes (2007 [2006]), de Jonathan Littell. Pretendemos evidenciar como o estudo da memória de um ex-oficial nazista pode influenciar a história da Segunda Guerra Mundial, atando e desatando os nós entre memória, história e ficção. O autor traz a história da maldade humana camuflada pelas vestes grossas dos oficiais de guerra. Por isso, muito além dos estudos da literatura de testemunho, Jonathan Littell permite que sua obra seja ponto de discussão para diversos temas. Neste trabalho, nos pautaremos em autores como Seligmann-Silva (2003), Halbwachs (1990), Assmann (2011), Seixas (2004), entre outros.

Palavras-chave: Memória. História. Literatura de testemunho. Ressentimento. As Benevolentes. 
[...] eu pensei naquele olhar tão estranho que havia em todos os rostos daquele acampamento; um olhar incompreensivel, que nunca se verá na Inglaterra, ainda que haja guerras na Inglaterra; e que também não se vê em nenhuma batalha. [...]

Nunca um pintor conseguirá retratá-lo e nem tampouco um ator reproduzi-lo. E para descrevê-lo, eu acho que tenho que voltar para lá e ficar com eles (trecho de uma carta do poeta Wilfred Owen)

\section{No RASTRO DE SANGUE}

$\mathbf{N}$ a mitologia grega são chamadas erínias, na mitologia romana são as fúrias, também chamadas benevolentes, conhecidas por sua aparição na tragédia grega Eumênides (do grego, bondosas ou benevolentes), de Ésquilo: as três divindades que punem os mortais que derramam do próprio sangue. O crime de sangue foi cometido, as três figuras buscam o culpado. Estamos diante de um oficial nazi, de vestes puídas pela guerra e mãos ensanguentadas. $O$ vermelho que escorre vem daqueles tidos como malditos, de uma "raça impura". Advém dos tiroteios em florestas abertas, das valas rasas, das forcas e do gás entre aquelas quatro paredes dos campos de concentração. Mas vai além. Seu sangue atinge o próprio umbigo, volta para o seu próprio ventre, de sua mãe, morta a machadadas - ele ainda sente o peso do machado arder em seus braços. Os respingos atingem os seus colegas alemães, o mesmo "sangue puro" seu escorre, também, entre as "impurezas" dos judeus. Sozinho, observando a trilha vermelha que o rodeia, seu "testemunho" termina, pois é sabido seu destino: "As Benevolentes haviam encontrado meu rastro" (LITTELL, 2007, p. 896).

Ao final das quase 900 páginas, Jonathan Littell evidencia a influência da figura mitológica que dá título ao seu romance, As Benevolentes. Littell nos prega peças desde o início: nova-iorquino de origem judaica, escreve seu livro originalmente em francês. Sendo de descendência judaica, esperamos que seu romance sobre a Segunda Guerra Mundial apresente o foco das literaturas de testemunho populares, como a corresponder a seu próprio eu-autor enquanto judeu; todavia, somos enganados. Estamos expostos aos fragmentos de memória de Maximilien Aue, um oficial da SS, participante dos períodos de exterminação dos judeus na Europa, das experiências do front em Stalingrado, organizador dos campos de concentração e presente, também, na derrota final dos nazistas. Temos a ideia da literatura de testemunho às avessas, o que leva Patrícia Alves Lourenço (2012, p. 3, grifo nosso), em "As Benevolentes, de Jonathan Littell: variações sobre o tema do mal", considerar "a obra de Littell inaugural de um novo estilo literário - a literatura de carrasco".

Ainda de acordo com Lourenço (2012, p. 6), notemos que a narrativa em As Benevolentes é dividida em dois planos distintos: "o primeiro - horizontal é aquele onde tem lugar o discurso do carrasco sobre a II Grande Guerra e o Holocausto. O segundo plano - vertical - centra-se na tragédia familiar do narrador". Além de descrever a guerra com os detalhes históricos já conhecidos, estamos diante das tragédias pessoais do narrador: a paixão incestuosa por sua irmã gêmea, Una; a relação conturbada com a mãe; a busca por relações homossexuais; a insanidade como fuga do "real" que o atormenta. Somos expostos a tais ocorrências pela voz do próprio narrador, que inicia sua narrativa como um 
colega próximo que nos dirige a palavra diretamente, sem as paredes ficcionais entre leitor-narrador-autor:

Irmãos humanos, permitam-me contar como tudo aconteceu. Não somos seus irmãos, vocês responderão, e não queremos saber. É bem verdade que se trata de uma história sombria, mas também edificante, um verdadeiro conto moral, garanto a vocês. Corre o risco de ser um pouco longa, afinal aconteceram muitas coisas, mas, se calhar de não estarem com muita pressa, com um pouco de sorte arranjarão tempo. Além do mais, isso lhes diz respeito: vocês verão efetivamente que lhes diz respeito. Não pensem que estou procurando convencê-los do que quer que seja; afinal de contas, cada um tem sua opinião. Se resolvi escrever, depois de todos esses anos, foi para expor as coisas para mim mesmo, não para vocês (LITTELL, 2007, p. 11).

Somos expostos ao indivíduo no seu íntimo: a crueldade humana, a "desumanização" dos homens, o mal em sua raiz mais profunda. Pretendemos seguir o rastro de sangue de Aue, este que nos exibe os corpos nus dos judeus feridos sem mediações, toca a sinfonia ${ }^{1}$ das cordas penduradas em sacadas de uma guerra que ainda continua em todos nós. Tendo como foco suas memórias, buscamos, a princípio: 1 . discutir a relação entre memória e história com base em estudos sobre a literatura de testemunho e a Shoah; 2. explorar as memórias do eu e a influência de suas "cicatrizes"; 3. abordar o ressentimento como consequência dessa experiência. Iniciaremos, portanto, com a discussão entre a história da Segunda Guerra Mundial e os seus desdobramentos a partir de reflexões sobre literatura e memória.

\section{PARA OS MORTOS}

A literatura de testemunho, comumente relacionada aos relatos, sejam reais ou fictícios, das guerras, é quase sempre sobre os mortos e, principalmente, para os mortos $^{2}$, em busca dos corpos que, em sua maioria, ficaram perdidos entre os escombros de um forno, de uma câmara, ou apodrecidos em uma viela. A narrativa constrói a lápide para a ausência que continua latente na memória daqueles que permaneceram, fugiram ou foram "redimidos". Desse modo, ao abordarmos a literatura sobre a Segunda Guerra Mundial, estaremos sempre lidando com uma falta e, ao mesmo tempo, com uma necessidade de não esquecer. Em História, memória e literatura, Seligmann-Silva (2003, p. 54) comenta sobre a importância da memória para o periodo de guerra:

A necessidade de testemunhar Auschwitz fica clara se nos lembrarmos dos inúmeros livros de memória redigidos logo após aquela tragédia. Os chamados Yizkor Bikher, cerca de 400 foram publicados, não são nada mais do que uma

\footnotetext{
Aue pode ser considerado um oficial nazi "culto". Ao longo da narrativa, ele cita Sófocles, Platão, Voltaire, Heródoto e, inclusive, nas páginas finais, enquanto foge para se libertar dos russos, leva consigo uma edição de $A$ educação sentimental, de Flaubert. Cita também alguns nomes clássicos da filosofia, como Heidegger e Sartre, e chega até mesmo a inserir Jung como um "personagem", já que ele teria sido o professor de sua irmã, Una. Conjuntamente, a música clássica é frequente no decorrer do romance. Sua irmã é casada com Von Üxküll, um músico que teve que se aposentar devido a um acidente. Além de citar alguns compositores, notemos que o próprio livro é organizado a partir de nomes de composições musicais: "Toccata", "Allemandes I e II", "Courante", "Sarabande", "Minuet (em rondeaux)", "Air" e "Gigue". Caso aprofundemos nossos estudos sobre tais composições, veremos que, por exemplo, a "Gigue" aparece ao fim de uma suíte, assim como está localizada ao final da narrativa de Littell.

2 Jonathan Littell traz como dedicatória em As Benevolentes: "Para os mortos".
} 
continuidade tanto da tradição iconoclasta judaica como da outra face dessa tradição: a da escrita e da narração como meios de manter a memória.

A tradição está, desse modo, vinculada às memórias que são narradas. Caso prestemos atenção nos números, veremos que 400 publicações dos chamados "livros de memória" ainda não serviriam para o funeral de um único dia do exterminio de judeus durante a guerra. Se tomarmos a narrativa de Littell como "historicamente verdadeira", ou pelo menos como uma base verídica dos fatos, veremos que os números são assustadoramente maiores:

Podemos também efetuar um cálculo definindo o intervalo de tempo entre cada morte: isso nos dá em média um morto alemão a cada 40,8 segundos, um morto judeu a cada 24 segundos e um morto bolchevique (incluindo judeus soviéticos) a cada 6,12 segundos, ou seja, isso para o conjunto do mencionado periodo. Agora vocês estão em condições de efetuar, a partir desses números, exercícios concretos de imaginação. Peguem por exemplo um relógio e contem um morto, dois mortos, três mortos etc. a cada 4,6 segundos (ou a cada 6,12 segundos, a cada 24 segundos ou a cada 40,8 segundos, se tiverem uma preferência definida), tentando imaginar, como se estivessem à sua frente, alinhados, estes um, dois, três mortos. Vocês verão, é um bom exercício de meditação. Ou peguem outra catástrofe, mais recente, que os tenha afetado intensamente, e façam a comparação (LITTELL, 2007, p. 22-23).

A ironia ao comentar sobre os mortos estirados sobre os ponteiros do relógio enquanto o tempo passa parece fazer reviver os segundos de cada tiro, os passos agonizantes dos judeus para as entradas fechadas de florestas, o bater lânguido das pás em suas próprias covas, o piscar dos olhos de súplica diante das portas fechadas do campo, da câmara, do forno. O pequeno número que temos ainda não alcança os portões dos campos, continuamos distantes de qualquer realidade possível. As memórias ilustram o que os livros de história deixam encoberto em suas entrelinhas. E, assim, entramos nos limites em que memória e história se chocam, ora se complementando, ora se contradizendo.

A princípio, podemos inferir que a principal diferença entre memória e história é a objetividade: enquanto a memória teria como característica o subjetivismo, na história, poderíamos estar perante uma objetividade, como aquela que se crê existir na "ciência". Conforme Jacy Alves Seixas (2004, p. 40-41), em Percursos de memórias em terras de história: problemáticas atuais:

[...] a memória é tradição vivida - "a memória é vida" - e sua atualização no "eterno presente" é espontânea e afetiva, múltipla e vulnerável; a história é o seu contrário, uma operação profana, uma reconstrução intelectual sempre problematizadora que demanda análise e explicação, uma representação sistematizada e crítica do passado.

Contudo, com o passar dos anos, a dicotomia entre ambas vem se estreitando, estabelecendo uma proximidade maior na relação entre história e memória. Pois é justamente a partir da memória que a história é constituída, sendo aquela a principal fonte para o conhecimento do passado:

Recentemente, a partir da década de 80, a historiografia vem afirmando a noção diversa; ela toma consciência de que a relação memória-história é mais uma 
relação de conflito e posição do que de complementaridade, ao mesmo tempoaqui se inscreve a novidade da crítica - em que coloca a história como senhora da memória, produtora de memórias (SEIXAS, 2004, p. 39, grifo do autor).

Ao utilizarmos a memória como base para a história, esta sofre algumas modificações. É preciso que ela seja recompatibilizada, ou seja,

[...] a temática da memória é aproximada em demasia da noção de história, de tal forma que uma união simbiótica se efetua e se acaba por aplicar os procedimentos e mecanismos da memória, aqueles que reconhecemos de longa data como historiográficos (SEIXAS, 2004, p. 41).

Por mais que a memória esteja se aproximando da história, adotando suas formas, há a necessidade de "cientificizá-la" a fim de servir aos moldes historiográficos, o que acarreta o esquecimento de uma das características fundamentais da memória: a subjetividade, o sentimento, o eu que viveu e sofreu todas aquelas lembranças. Tal interpretação pode ser complementada pelo comentário de Seligmann-Silva (2003, p. 67) sobre a consequência de sua relação com a história: "não existe uma História neutra; nela, a memória, enquanto uma categoria abertamente mais afetiva de relacionamento com o passado, intervém e determina em boa parte seus caminhos", isso porque a memória apenas "existe no plural: na sociedade dá-se constantemente um embate entre diferentes leituras do passado, entre diferentes formas de 'enquadrá-lo"'. Acreditamos no objetivismo da história, em sua não subjetividade por se tratar de um "documento", contudo, nos esquecemos daquilo que a estrutura: as memórias. É por isso que, como salienta Seixas (2004, p. 42, grifo do autor), há uma dificuldade em tentar distingui-las:

Dificil, então, perceber quais distinções entre memória e história (ainda que não sejam dicotômicas...), porque memória passa a identificar-se com história. Ou seja, a memória e o esquecimento aqui também só existem sob os olhares da história, investindo-se na reconstrução de novas identidades, a partir de um critério utilitário-politico. "Toda memória, seja ela 'individual', 'coletiva' ou 'histórica', é uma memória para qualquer coisa, e não pode ignorar esta finalidade política (no sentido amplo do termo)"3.

Em As Benevolentes, a dicotomia se torna ainda mais difusa: além do jogo memorialístico e histórico, temos agora a inserção da ficção. Imersos nos anos do auge do nazismo, diante de personagens "reais" como o próprio Führer e seus oficiais mais devotos, como Heydrich, Himmler e até mesmo Goebbels, aceitamos a venda histórica e acreditamos de partida no jogo bem articulado de Littell. É por isso que Emília Amaral (2012, p. 2), em "As benevolentes, de Jonathan Littell: o cruzamento entre ética e estética, na representação do Holocausto", ressalta a proximidade com o romance histórico:

[...] um primeiro ponto importante a ser lembrado é a sobredeterminação do aspecto documental de As Benevolentes e a verificação de como esse aspecto convive com o romanesco, ou, melhor dizendo, como ele é absorvido pelo romanesco.

3 O trecho citado ao final do excerto, conforme nota disponibilizada por Seixas, pertence a "Patrick J. Geray, La mémoire et l'oubli... [...], p. 31". 
Seguimos cegamente o caminho conhecido pela história, ditado em manuais e didatizado nas escolas, até que as fugas de Littell nos sobressaltem e destruam as certezas antes tão bem articuladas.

Em meio a uma cerimônia na qual oficiais recebem medalhas devido aos seus méritos durante a guerra, mesmo que esta esteja prestes a acabar e a derrota seja iminente, somos surpreendidos com o desvio brusco da ficção. O próprio Hitler começa a ser desconfigurado diante de nossos olhos: "eu nunca reparara a que ponto aquele nariz era largo e desproporcional” (LITTELL, 2007, p. 882). $\mathrm{E}$, conforme a sua aproximação para entregar a medalha a Aue, a imagem se desfoca e se descontrói até atingir o auge:

O Führer aproximava-se e eu continuava a observá-lo. Então ficou à minha frente. Constatei com espanto que seu quepe mal batia na altura dos meus olhos; $e$, não obstante, não sou alto. Ele murmurava seu cumprimento e procurava a medalha às apalpadelas. Seu hálito ácido, fétido, foi a gota d'água: era realmente demais para suportar. Então me projetei e mordi seu nariz bulboso com toda a força, até sangrar. Ainda hoje eu seria incapaz de lhes dizer por que fiz aquilo: simplesmente não consegui me controlar (LITTELL, 2007, p. 882-883).

Seguimos então a procurar registros de algum oficial que tenha ferido Hitler de alguma maneira e nos vemos diante de páginas em branco. Preparado, Littell traz prontamente em sua narrativa a resposta que buscávamos: "Sei muito bem que Trevor-Roper não disse uma palavra acerca desse episódio, Bullock tampouco, assim como todos os outros historiadores que se debruçaram nos últimos dias do Führer. Entretanto, asseguro-lhes, aconteceu" (LITTELL, 2007, p. 883, grifo nosso). A veemência com que afirma o fato insere a dúvida, ficamos presos entre a história, a memória e a ficção. Está claro que, quando nos referimos a textos literários, como o de Jonathan Littell, temos a ficção como um forte ponto a ser considerado. Isso porque nos vemos diante de um embate: literatura versus o "real":

Literatura de testemunho é um conceito que, nos últimos anos, tem feito com que muitos teóricos revejam a relação entre a literatura e a "realidade". O conceito de testemunho desloca o "real" para uma área de sombra: testemunha-se, via de regra, algo de excepcional e que exige um relato. Esse relato não é só jornalístico, reportagem, mas é marcado também pelo elemento singular do "real" (SELIGMANN-SILVA, 2003, p. 47).

Até que ponto uma literatura de testemunho às avessas, ou uma literatura de carrasco, distingue o "real" do ficcional? O embate entre as memórias de Aue, por vezes ilusórias e oníricas, se mistura com as batalhas do front tão bem documentadas, com as descrições cruas dos espancamentos e torturas de judeus que também são conhecidas (por meio das próprias testemunhas). De acordo com Amaral, as passagens em que Jonathan Littell joga conosco, como, por exemplo, a cerimônia das medalhas, "converte o suposto romance histórico realista em decalque de comédia pastelão, desnorteando o leitor" (AMARAL, 2012, p. 4). Isso porque, de acordo com a autora, a perspectiva histórica parece se sobrepor a qualquer outro aspecto no romance:

Tal articulação entre, de um lado, a visão caricata dos nazistas num texto em primeira pessoa supostamente narrado por um deles, e, de outro, a intensidade 
das cenas que descrevem o sofrimento das vítimas, constitui o "núcleo duro" do livro, o que ele apresenta de vital ao conhecimento ou reconhecimento do leitor, sem benevolências nem facilitações redutoras, embora saibamos da particular indizibilidade de sua matéria. Nesse sentido, os capítulos referentes à Guerra e às etapas do Holocausto, isto é, ao tema histórico, quais sejam - cap. 2: "Alemandes I e II - a shoá por tiros", cap. 3: "Courante", o cerco de Estalingrado; cap. 5: "Minuet”, en rondeaux, os campos de concentração; cap. 7: “Gigue”, a queda de Berlim - me parecem mais eficazes que aqueles destinados ao tema abordado a partir do mito, centrados na personalidade patológica do narrador protagonista. Isso pelo fato de que nestes últimos - cap. 1: "Toccata", "prelúdio" introdutório; cap. 4: "Sarabande", o matricídio; cap. 6: "Air" (o refúgio do narrador na casa de sua irmã gêmea) - a figura do perpetrador, como já afirmamos, jamais se torna crível ao leitor. Ao contrário, a superposição de mascaramentos, de referências literárias e particularmente psicanalíticas com a qual é tecida, avoluma, sem grande produtividade, o gigantismo do romance (AMARAL, 2012, p. 6).

A narrativa de Littell é recortada entre momentos cruamente descritivos das torturas dos judeus e atrocidades da guerra, como bem aponta Amaral, e das "filosofias" de Aue diante da crueldade humana, e, ainda, dos seus delírios e momentos de quase insanidade. Nesse resumo rápido da estrutura do enredo, podemos delimitar uma espécie de gradação em desenvolvimento: temos a história como base (a guerra e suas atrocidades), as elucubrações de um oficial perante o desespero humano diário e, por fim, como um cerne a ser atingido: a sua quase insanidade após momentos de grande choque (o primeiro ocorre depois de ser atingido por uma bala, e o segundo, após uma breve participação no front de Stalingrado). Ao contrário do que postula Amaral, podemos notar que as cenas de delírio de Aue são, na realidade, o mais próximo que ele consegue chegar do "real" na história da guerra. Por mais que não tenha sido ele um dos judeus, temos a teoria da literatura de testemunho a nosso favor, como aponta Seligmann-Silva: “Testemunha-se um excesso de realidade e o próprio testemunho enquanto narração testemunha uma falta: a cisão entre linguagem e o evento, a impossibilidade de recobrir o vivido (o 'real') com o verbal" (SELIGMANN-SILVA, 2003, p. 46). A linguagem se mostra falha e insuficiente diante da guerra, dos bombardeios, dos homens chupando manteiga e morrendo por diarreias.

As palavras não alcançam o todo, a descrição minuciosa de milhares de judeus sendo mortos por tiros cegos, seus gritos desesperados, suas preces e olhares de clemência não são suficientes. Porque, para atingir o eu, precisamos nos voltar para aquele que fala, adentrar seus escombros fatigados pela fome e disenteria, e ir além: invadir o eu abalado pelo medo e enxergar a loucura que se faz presente como um escape. Todavia, a insanidade dói. A vida em reclusão na casa de Una, sua irmã e amante, nos momentos quase finais da narrativa, não o salva das agonias de morte, das visões do que se passou e de quem ele matou, do amor inalcançável, da vontade de ferir o corpo em busca de um prazer que não existe. Os detalhes dos seus sadismos, a masturbação frequente e doentia, os delírios de conversas, o ataque ao próprio corpo são tão frios quanto os momentos em que Aue excruciantemente descreve as mortes de outros. A grandiosidade do romance reside exatamente nesse ponto, em que o pavor do mundo se choca com o pavor de um eu diante de tamanha desolação humana. 
A linguagem se volta contra o eu e, como nos jatos quentes de merda que Aue descreve detalhadamente, jorra contra nós, leitores, exibindo os detalhes mais fétidos e escatológicos do ser humano no seu íntimo.

A impossibilidade de alcançar o "real" por meio das palavras exige da linguagem uma quebra. Para Seligmann-Silva, a linguagem "é antes de mais nada o traço - substituto e nunca perfeito e satisfatório - de uma falta, de uma ausência” (SELIGMANN-SILVA, 2003, p. 48). Littell transforma a falta em exagero: temos uma narrativa longa e pesada, com seu alcance de quase 900 páginas de romance. A esse respeito, o próprio narrador-personagem nos alerta logo no início: "Corre o risco de ser um pouco longa, afinal aconteceram muitas coisas, mas se calhar de não estarem com muita pressa, com um pouco de sorte arranjarão tempo" (LITTELL, 2007, p. 11), e continua: "Se resolvi escrever, depois de todos esses anos, foi para expor as coisas para mim mesmo, não para vocês" (LITTELL, 2007, p. 11).

Alertados, logo no início do romance, de que estamos diante das memórias de um eu, passemos agora a ouvi-las com mais atenção, ler entre as suas cicatrizes aquilo que grita dentro do corpo, as angústias e medos de um oficial que resolveu contar-nos, ou contar para si próprio, os rastros que seu sangue percorreu.

\section{Eu Testemunha, EU CICATRIZ}

$\mathrm{Na}$ primeira página do romance, Max, um fabricante de renda com família, trabalho e responsabilidades, introduz a sua narrativa convidando-nos para ouvir as suas recordações:

Recordações são coisas que eu tenho, e inclusive em uma quantidade considerável. Sou uma verdadeira fábrica de recordações. Teria passado a vida fabricando recordações, ainda que agora me paguem, em vez disso, para fabricar renda (LITTELL, 2007, p. 11-12).

Alerta-nos sobre a provável extensão longa, sobre a proximidade da história com nós mesmos e sobre seu "péssimo senso de humor". E assim, logo em seguida, descobrimos o seu passado, a ser recontado com a exatidão de um presente. As memórias de um eu que descreve, com a precisão já anunciada - "quero ser preciso, na medida do possivel” (LITTELL, 2007, p. 13) -, sua participação em um dos períodos mais cruéis da história da humanidade.

De forma a introduzir nossas discussões a respeito das memórias individuais de Aue, damos continuidade aos estudos de Seligmann-Silva sobre a literatura da Shoah. O autor aponta que ela e a historiografia do nazismo

[...] encontram-se diante do desafio de criar vasos comunicantes tanto entre os diferentes foci dos envolvidos na história como também de dar conta de uma memória que resguarde tanto a singularidade do evento quanto a continuidade histórica que ele significou (SELIGMANN-SILVA, 2003, p. 75, grifo do autor).

Como em um quebra-cabeça, as duas peças colaboram para que a história seja formada. Diante da narrativa de um oficial nazi, podemos analisar as atrocidades por dentro do mundo fechado dos uniformes, da pobreza dos soldados, dos pés congelados diante da imensidão soviética e do sadismo nascente de uma tortura ininterrupta. 
Para o reconhecimento de um evento, como um todo e no coletivo, Maurice Halbwachs (1990, p. 25), em A memória coletiva, coloca o testemunho como uma forma de "fortalecer ou debilitar, mas também para completar, o que sabemos de um evento do qual já estamos informados de alguma forma, embora muitas circunstâncias nos permaneçam obscuras", concluindo: "Ora, a primeira testemunha, à qual podemos sempre apelar, é a nós próprios”. É por isso que, ao lermos a narrativa de Aue, o jogo entre narrador e personagem nos leva a imergir com mais profundidade em um evento já tão discutido. Um eu que viu e sentiu, com seus olhos e corpo, o frio dos judeus diante da corda, roubou seus casacos mais grossos na sala anterior aos assassinatos, ouviu o primeiro choro de um bebê judeu e o som frouxo de seus ossos esmagados pelas mãos de um oficial, comeu a lavagem fria da guerra, viu a estatura mediana do Führer, seu cheiro acre... mordeu o nariz do Führer durante uma cerimônia?

Nesse ponto, temos um embate. Isso porque, como Halbwachs (1990, p. 28) salienta,

Pode ser que essas imagens reproduzam mal o passado, e que o elemento ou a parcela de lembrança que se achava primeiramente em nosso espírito, seja sua expressão mais exata: para algumas reais junta-se assim uma massa compacta de lembranças fictícias.

$\mathrm{O}$ eu, adotado como testemunha, rediz e descreve, porém também ficcionaliza, pois a verdade por vezes é árdua demais para que seja recuperada com exatidão. Ocorre o que Seligmann-Silva (2003, p. 82) chama de estetização da catástrofe, em que "a metáfora fica bloqueada diante da manifestação do mal absoluto da morte em um grau até então desconhecido; [...] querem mostrar não apenas os traços do passado, mas a impossibilidade de reinscrevê-los de modo total". A todo momento, sozinhos ou em um grupo, somos passiveis de confundir os passados, trocar as memórias, ficcionalizar.

Os estudos de Halbwachs partem para a ideia de que a memória é, em sua essência, coletiva. Mesmo nos momentos em que pensamos estar sozinhos e ter uma lembrança apenas nossa, "temos sempre conosco e em nós uma quantidade de pessoas que não se confundem” (HALBWACHS, 1990, p. 26). A influência do coletivo no eu afeta não somente suas memórias, mas todo um comportamento humano. Podemos ver isso claramente no nazismo, em que um pequeno grupo, em convivência com os demais, conseguiu convencer populações gigantescas de seus ideais. Halbwachs (1990, p. 47) discorre sobre a nossa ilusão de autonomia diante de uma força coletiva:

[...] acontece mesmo frequentemente que a dosagem de nossas opiniões, a complexidade de nossos sentimentos e de nossas preferências não são mais que a expressão dos acasos que nos colocaram em relação com grupos diversos ou opostos, e que a parte que representamos em cada modo de ver está determinada pela intensidade desigual das influências que estes têm, separadamente, exercido sobre nós. De qualquer maneira, na medida que [sic] cedemos sem resistência a uma sugestão de fora, acreditamos pensar livremente.

Mesmo que Aue, durante o extermínio de um grupo de judeus, se recuse a atirar no primeiro grupo, a força da tradição continua a puxá-lo para o centro e a tomar a próxima arma vaga. As suas fugas, ou seus diálogos fictícios com filó- 
sofos, fazem com que a ideia de liberdade apenas se insira, mas não se concretize. Talvez seja por esse motivo que, durante a narrativa de Littell, enquanto Aue se mistura com um grupo e se sente pressionado por ele, suas memórias se tornem muito mais criveis e fáceis para nós, enquanto leitores. Halbwachs (1990, p. 49) distingue a memória individual da coletiva esclarecendo essa questão:

[...] os fatos e noções que temos mais facilidade em lembrar são do domínio comum, pelo menos para um ou alguns meios. Essas lembranças estão para "todo mundo" dentro desta medida, e é por podermos nos apoiar na memória dos outros que somos capazes, a qualquer momento, e quando quisermos, de lembrá-los. [...] Por mais estranho e paradoxal que isto possa parecer, as lembranças que nos são mais dificeis de evocar são aquelas que não concernem a não ser a nós, que constituem nosso bem mais exclusivo, como se elas não pudessem escapar aos outros senão na condição de escapar também a nós próprios.

As memórias coletivas, entre os soldados ou demais oficiais, são descritas com total destreza e alinhadas com as populares descrições históricas da guerra. Estabelecemos confiança com o relato, a cada página reforçamos a nossa crença naquilo que está sendo descrito e queremos acreditar no "real". O quadro muda quando a porta da casa de Una é fechada e os únicos passos que ouvimos são os de Aue durante um período indeterminado de dias, uma série de diálogos mudos com pessoas que não existem, descrevendo as dores da sua própria carne, que beira o abismo da sanidade. Invadimos o seu interior mais obscuro e lodoso. O sangue da guerra, dos ferimentos e cicatrizes, escoa pelas páginas amareladas. A dor se insere na memória como uma ferida, e quanto mais o personagem busca encontrar a si mesmo, mais o dedo mergulha na carne gelatinosa do buraco da bala - e o eu beira a perdição, para sempre.

Assim, avançamos nas memórias do eu e seguimos para a leitura de suas cicatrizes. Aleida Assmann, em Espaços da recordação: formas e transformações da memória cultural, discute a relação da memória com a dor e, principalmente, com o corpo. De acordo com a autora, a relação entre dor e memória foi posta por Nietzsche:

Sua tese sobre a "dor como o acessório mais poderoso da mnemotécnica", Nietzsche a desenvolveu em uma retórica simples de pergunta e resposta. Sua pergunta: "Como se cria uma memória para o animal humano? Como se entalha nesse entendimento de natureza instantânea, em parte embotado, em parte confuso, nesse esquecimento encarnado, alguma coisa de modo que ela permaneça ali?". E a resposta: "Marca-se a fogo, e com isso alguma coisa ficará na memória; só o que não termina, o que dói, fica na memória” (ASSMANN, 2011, p. 263, grifo do autor).

A literatura de testemunho daqueles tanto ridicularizados, torturados, mortos, estaria confirmando a teoria de Nietzsche: há uma memória latente, um corpo que ainda dói, as cicatrizes, físicas e psicológicas, continuam a lembrá-los das noites insones, dos barulhos dos tiros, do cheiro acre das chaminés. O outro lado da guerra também mantém as cicatrizes; a própria Assmann refere-se às cicatrizes físicas dos soldados tidas como orgulho diante dos seus generais (cf. ASSMANN, 2011, p. 264). A dor continua a acordá-los durante a noite, o grito não cessa: 
[...] existem homens para quem a guerra, ou mesmo o assassinato, é uma solução, mas eu não sou desses; para mim, como para a maioria das pessoas, a guerra e o assassinato são uma pergunta, uma pergunta sem resposta, pois, quando se grita à noite, ninguém responde (LITTELL, 2007, p. 30).

Os dias se sucedem, tornam-se anos, a guerra acaba e o antigo oficial hoje fabrica rendas para sustentar uma família. Contudo, o eco continua a ressoar entre as paredes do quarto, da sala, da fábrica. A pergunta segue sem resposta, e as memórias corroem um crânio marcado pela bala, os arranhões e os ferimentos que ficaram. Isso porque, conforme Assmann (2011, p. 265), a partir de sua leitura de Nietzsche, a memória está associada à "fixação de um presente constante. O que será confiado à memória não precisa apenas manter-se indelevelmente inesquecivel, mas também permanentemente presente". Enquanto a narrativa está sendo contada, o verbo presentifica o ato passado.

Nessa constante, de "rememorar a tragédia e enlutar os mortos", como diz Seligmann-Silva (2003, p. 52), estamos diante da narrativa do trauma:

[...] tarefa árdua e ambígua, pois envolve tanto um confronto constante com a catástrofe, com a ferida aberta pelo trauma - e, portanto, envolve a resistência e a superação da negação -, como também visa a um consolo nunca totalmente alcançável.

O corpo, tanto o do próprio narrador quanto o daquele terceiro que ele descreve detalhadamente, é agora marcado pelas feridas das batalhas, e as rememorações se mesclam e transformam-se: o corpo é a memória, o corpo é a guerra em sua total destruição do ser. As lembranças de Aue de um de seus amantes marcam exatamente a união entre corpo e guerra, na qual o personagem enxerga, em cada um de seus membros, um ferimento que ainda não explodiu:

Quando contemplava o belo corpo nu de Partenau, já cruelmente ferido, uma angústia surda me invadia: se passasse meus dedos no seu mamilo, arrepiando o bico, depois em sua cicatriz, imaginava esse seio novamente esmagado pelo metal; quando beijava seus lábios, via seu maxilar arrancado por um estithaço de shrapnel em chamas; e, quando descia entre suas pernas e mergulhava em seus órgãos luxuriantes, sabia que em algum lugar uma mina esperava, prestes a retalhá-los. Seus braços fortes e coxas ágeis eram igualmente vulneráveis, uma semana, quem sabe amanhã, toda aquela carne tão bela e macia podia transformar-se num átimo, em carne de açougue, em uma massa sangrenta e carbonizada (LITTELL, 2007, p. 193).

O corpo transformado em simbolo, a cicatriz instaurada em um todo de membros e ossos, esmagado pelo metal, ferido pelas bombas, retalhado como as carnes penduradas em um açougue. O narrador-personagem tem, presas em sua pele, nos escombros dos músculos, no buraco da bala, todas as recordações que o assolam e não silenciam. O próprio corpo de Aue sofre com as suas cicatrizes, e cada qual acompanha um episódio de total exílio do "mundo real" em que ele está preso. Após a bala recebida na cabeça segue um episódio de fantasias, em que ele pode rever sua amada irmã, seu colega Voss ainda sangrando, e nadar entre as águas gélidas de Stalingrado sem sentir frio. Em outro ângulo, enxergamos o corpo do oficial, jogado entre tantos feridos ao relento, atingido seriamente na cabeça, que continua a respirar. 
A partir da leitura das cicatrizes do personagem, seguimos, ainda, seu rastro de sangue e dor através do caminho obscuro do eu. Alcançamos o cerne, atingimos o mais profundo da memória: o ressentimento do que se passou, do que foi, do que eles foram, do que se tornou e do que é.

\section{As mãos suJas de SANGUe}

Retomemos a imagem inicial: o oficial nazi, de uniforme gasto, com as mãos sujas de sangue seco a perder-se em seus próprios rastros. Essa é a figura que carregamos agora nos delírios finais de Aue. Sua batalha está chegando ao fim, já foram detalhados (e retalhados) tantos corpos, dos outros, e o seu próprio, que ansiamos pelo ponto final absoluto. Nesse momento, pretendemos evidenciar o ressentimento como a consequência final de seu testemunho.

Durante um encontro com Una, enquanto conversavam sobre o envolvimento de Aue com a SS, o narrador-personagem nos relata a aflição de sua irmã perante os novos ideais que vinham surgindo na Alemanha:

Ela me escutava bebendo vinho; eu bebia também, porém mais lentamente. "Não estou certa de partilhar do seu entusiasmo por esse Hitler", comentou. "Ele me parece neurótico, atormentado por complexos não-resolvidos, frustrações e ressentimentos perigosos" (LITTELL, 2007, p. 448).

A palavra "ressentimento" aparece no romance em diversos momentos, e cada aparição parece conter um significado diferente. O próprio termo carrega em si essa significação ambígua, inconclusa.

Em História de uma emoção, David Konstan busca "traduzir" o termo, partindo, inicialmente, de sua origem. Durante sua pesquisa, ele ressalta os estoicos como uns dos pioneiros a se aproximarem de um conceito. Contudo, de acordo com o autor, a palavra estaria hoje sendo traduzida para o inglês como "inveja" (cf. KONSTAN, 2004, p. 61). Por isso, notemos que a dificuldade em encontrarmos uma noção exata para o termo faz com que as muitas vezes em que ele aparece no romance apontem para significados diferentes. O que facilita seu entendimento, de acordo com Konstan, seria relacioná-lo com outros temas. O ressentimento em um sentido existencialista, por exemplo, "parece sugerir um estado ou sentimento persistente, em vez de uma reação a um estímulo particular imediato" (KONSTAN, 2004, p. 62). Como se, voltando-nos para o romance de Littell, a dor latente das memórias de seu narrador fosse a causa para o seu ressentimento. Temos a confirmação na voz do próprio personagem que, imerso em um mundo de delírios e solidão durante a estadia na casa de Una, conclui:

Fui me sentar sobre uma arca ao pé da cama, em frente ao grande espelho. Contemplei o homem à minha frente, um indivíduo amorfo, cansado, taciturno, fisionomia inchada de ressentimento. Eu não o reconhecia, aquilo não podia ser eu, mas não obstante era (LITTELL, 2007, p. 808).

O homem do ressentimento prostra-se diante de nós.

De um outro ponto de vista, Pierre Ansart (2004, p. 26), em História e memória dos ressentimentos, relaciona o ressentimento ao Estado, corroborando a visão do período nazista e o sentimento de ódio dominante dos soldados:

Pode-se acrescentar, ainda, que os regimes totalitários, fascista ou comunista, tiveram como estratégia ideológica favorecer a formação de um ódio dominante, 
um ódio exclusivo, e exacerbá-lo com fins de mobilização coletiva. Para o regime nazista, o ódio dos governantes e das nações vitoriosas de 1918; para o regime stalinista, o ódio dos capitalistas e proprietários. Estes regimes tiveram em comum integrar em sua ideologia um ódio dominante, um ressentimento de Estado, que possibilitava a ocultação dos ressentimentos internos contra os dominantes e governantes no interior do regime estabelecido.

Vemos, descrito pelos olhos de um oficial nazi, que os demais soldados, em sua maioria, aceitavam o que lhes era pedido e não se revoltavam. Pelo contrário, a atitude agressiva e desumana que deviam exercer transformou-os em sadistas: a dor do sofrimento dava-lhes prazer. Imersos em um mundo de violência e ódio, a agressividade torna-se parte do próprio eu. De acordo com Ansart (2004, p. 24), com base em Freud, "o sujeito busca, da melhor forma, integrar as pulsões de agressão e, assim, o ódio lhe é parcialmente estruturante”. A influência dos governos totalitários é fator crucial: Ansart (2004, p. 25) observa que Freud

[...] não nega, de forma alguma, que os sistemas políticos possam favorecer, em maior ou menor intensidade, os ressentimentos ou que conjunturas particulares, como as guerras, levem à exacerbação dos ódios e provoquem, segundo suas palavras, o desencadeamento da barbárie.

Aue nos relata detalhadamente a sociedade sádica da barbárie, os "espectadores" em fila para ver os tiroteios em massa, as multidões diante dos enforcamentos públicos, as fotos de tortura trocadas como um álbum de figurinhas da desumanização entre os oficiais.

De volta para o eu e o seu próprio ressentimento, notemos que, por mais dificultosa que seja a significação exata do termo, Pierre Ansart (2004, p. 15) elenca alguns sentimentos que ajudam a caracterizá-lo: "é preciso considerar os rancores, as invejas, os desejos de vingança e os fantasmas da morte, pois são exatamente estes os sentimentos e representações designados pelo termo ressentimento". Os fantasmas da morte atordoam Aue, que dialoga febrilmente com eles durante seu exílio. A morte caminha entre seus passos, a neve é manchada de vermelho, os membros soltos sem complemento lhe fazem companhia durante as fugas, o grito ensurdecedor do desespero final ecoa em seus ouvidos surdos pelas bombas. Ainda nos utilizando dos estudos de Konstan (2004, p. 74), este nos apresenta a imagem pintada por Edvard Munch como uma representação do homem ressentido: "os indivíduos tendem à introspecção e ao cultivo 'de si próprio e de suas vidas interiores' [...] O grito, de Edvard Munch, representa bem a imagem desse homem torturado e prisioneiro de si mesmo". A narrativa de Aue é seu próprio cárcere, estamos diante de seu corpo velho marcado pela memória da dor de Nietzsche, pelas cicatrizes de Assmann e, agora, remoendo os ressentimentos ditados por Konstan e Ansart e pintados por Munch. Diante do fim da guerra, enquanto observamos a última folha em branco do romance se aproximar, ele febrilmente relata:

Senti de repente todo o peso do passado, do sofrimento da vida e da memória inalterável e fiquei sozinho com o hipopótamo agonizante, alguns avestruzes e os cadáveres, sozinho com o tempo e a tristeza e a dor da lembrança, a crueldade da minha existência e a minha morte ainda por vir (LITTELL, 2007, p. 896).

A morte - e suas três mandantes - estava mais próxima do que nunca. 
O fim da guerra é oficializado pela história em 1945, período em que acabam as rememorações de Aue. Porém, se retomarmos suas palavras iniciais, já tão distantes e ao mesmo tempo tão próximas do nosso presente, veremos um ex-oficial que ainda parece querer se esconder dos bombardeios que não existem mais. Ele segura as rendas recém-fabricadas, vemos a linha alva descolorir-se pela cor vermelho-sangue de suas mãos, e este nos diz, como numa súplica final: "Mas vocês estão mesmo seguros de terem aprendido a lição? Têm certeza de que não acontecerá de novo?” (LITTELL, 2007, p. 23). A essa pergunta, Jonathan Littell não prepara uma resposta pronta no parágrafo seguinte.

Mas o rastro de sangue continua.

\section{O CONTRAPONTO FINAL DA "GIGUE"}

Ao fim de uma suite, eis a chamada "gigue", muitas vezes acompanhada por um contraponto, em que as vozes se sobrepõem num último suspiro prevendo o fim. Rebobinando a fita da história, reconhecemos os pontos cruciais do caminho vermelho descrito por Aue. Reconhecemos que a história constitui-se, em sua base fundamental, de memórias subjetivas do passado. É por isso que a busca de uma cientificidade, de fundamentos objetivos, como propunha Amaral (2012), acaba por ser ilusória e falsa. As memórias são recortadas e montadas de acordo com a visão daquele que fala e, como ressalta Seligmann-Silva (2003), estão sujeitas à ficcionalização. Isso porque, para que se atinja a memória, faz-se necessário o presente, e o trauma instaurado no corpo, marcado muitas vezes na pele, impossibilita que a linguagem alcance uma descrição fria e calculista. Para não falar dos tormentos da solidão, dos traumas da guerra que o enlouquecem, Aue invade o seu mais íntimo e nos descreve suas ilusões (d)e angústia.

Desse modo, percebemos que a linha que une e separa a memória-história e, por fim, a ficção, é difusa e borrada. Percorremos seus caminhos sem que sejam necessárias divisórias preestabelecidas, pois não é possivel delimitar onde uma termina e a outra começa. A narrativa de Littell joga com os três elementos, inserindo fatos históricos através da memória de um oficial que, muitas vezes, parece brincar com o leitor que espera, ansioso, pela "verdade". É nesse ponto que a memória coletiva e a memória individual, como propõe Halbwachs (1990), se instauram e confirmam a dificuldade de acreditarmos na memória de alguém que, rodeado de vazios, nos descreve cenas de sadismos e diálogos imaginários. O contrário são suas descrições da guerra, dos assassinatos e campos de concentração, já que o coletivo esteve sempre ali, reforçando a "veracidade" do que se passou e é sabido por meio de livros e demais relatos.

Aue leva suas memórias individuais dentro de cada cicatriz. O furo da bala marca uma narrativa que beira o fantástico, quebrando o "realismo" tão bem estruturado anteriormente. A memória está marcada pela dor, como aponta Nietzsche, seja dos ferimentos, seja da própria situação calamitosa que vê ao seu redor: mortos, feridos, membros esparsos, sangue e o cheiro podre de fezes. Assim, confirmamos a teoria de Assmann (2011), em que o corpo se torna o receptáculo das memórias, como figura Littell com seu narrador-personagem.

Por fim, diante do caos, seja em seu interior ou no mundo que parece estar se liquefazendo em sangue e torturas, surge o ressentimento como consequência. Isso porque, como bem apontam os teóricos Konstan (2004) e Ansart (2004), 
estamos diante de um sentimento que extrapola as significações, vai além daquilo que conhecemos popularmente como tristeza, dor e angústia. A marca na pele de Aue ressoa e a sinfonia ecoa a dor e a ânsia de um fim. Mas o ressentimento, como anteriormente discutido, continua a habitar o personagem tão bem articulado de Littell. Por isso, talvez, seja ele o ponto que corrobora a criação do ouroboros (figura da serpente que abocanha a própria cauda): os seus atos durante a guerra colaboraram para o ressentimento, e este, como consequência de seus atos, faz com que seja necessário expurgar os gritos durante a noite que não cessa, e revivê-los durante sua narrativa de memória. A dor é contínua, ele está sempre a reiniciar o seu ciclo exorcista que nunca expulsa, de fato, o demônio dentro de si.

Em resumo, vemos que As Benevolentes parece $(\mathrm{m})$ trazer em seu cerne as teorias da memória e seus afluentes. Essas figuras mitológicas que mergulham no passado mais obscuro dos personagens seguem seus rastros de sangue e confirmam a lenda de uma morte já anunciada desde o primeiro tiro. Na gigue, ao final da sinfonia, ouvimos então todas as vozes de teóricos se sobreporem à de Aue, mas não a silenciando, e, sim, corroborando o som harmônico do fim.

\section{The hangman's testimony: From memory to Resentment in As Benevolentes}

Abstract: A New Yorker writer that writes a novel in French. A Jewish descendance that twist and turns in a narrative told through the eyes of a nazi officer. We invert the roles in Les Bienveillantes (2006), by Jonathan Littell. We intend to evidence how the studies of memory of a former nazi officer can influence the history of the Second World War, tying and untying knots between memory, history and ficcion. The author brings the history of the human malice camouflaged by the thick robes of war offices. Thereupon, far beyond the studies of the testimony literature, Jonathan Littell allows his novel to be discussed in various topics. In this work, we will refer to authors such as Seligmann-Silva (2003), Halbwachs (1990), Assmann (2011), Seixas (2004), among others.

Keywords: Memory. History. Testimonial Literature. Resentment. Les Bienveillantes.

\section{REFERÊNCIAS}

AMARAL, E. As benevolentes, de Jonathan Littell: o cruzamento entre ética e estética, na representação do Holocausto. Arquivo Maaravi: Revista Digital de Estudos Judaicos da UFMG, Belo Horizonte, v. 6, n. 10, p. 1-10, mar. 2012.

ANSART, P. História e memória dos ressentimentos. Tradução Jacy Alves de Seixas. In: ASSMANN, A. Espaços da recordação: formas e transformações da memória cultural. Tradução Paulo Soethe. Campinas: Editora da Unicamp, 2011.

HALBWACHS, M. A memória coletiva. Tradução Laurent León Schaffter. São Paulo: Editora Revista dos Tribunais, 1990.

KONSTAN, D. Ressentimento: história de uma emoção. Tradução Carlos Galvão e Cristina Meneguello. In: BRECIANI, S.; NAXARA, M. Memória e (res)sentimento: indagações sobre uma questão sensivel. 2. ed. Campinas: Editora da Unicamp, 2004. p. 59-78. 
LITTELl, J. As Benevolentes. Tradução André Telles. Rio de Janeiro: Objetiva, 2007.

LOURENÇO, P. A. As Benevolentes, de Jonathan Littell: variações sobre o tema do mal. Extrema: revista interdisciplinar de humanidades, n. 1, p. 1-23, 2012.

SEIXAS, J. A. Percursos de memória em terras de história: problemáticas atuais. In: BRESCIANI, S.; NAXARA, M. Memória e (res)sentimento: indagações sobre uma questão sensível. 2. ed. Campinas: Editora da Unicamp, 2004.

SELIGMANN-SILVA, M. História, memória, literatura: o testemunho na Era das Catástrofes. Campinas: Editora da Unicamp, 2003. 